\title{
Analysis of Ceramics Using Scanning Electron Microscopy
}

\author{
Sujeong Lee Le $^{\dagger}$ \\ KIGAM \\ 이수정 ${ }^{\dagger}$ \\ 한국지질자원연구원/UST
}

\section{주사전자현미경을 활용한 세라믹의 분석}

(Received December 11, 2019; Accepted December 16, 2019)

\begin{abstract}
s
A ceramic is used as a key material in various fields. Accordingly, the use of scanning electron microscopy is increased for the purpose of evaluating the reliability and defects of advanced ceramic materials. The scanning electron microscope is developed to overcome the limitations of optical microscopy and uses accelerated electrons for imaging. Various signals such as SE, BSE and characteristic X-rays provide useful information about the surface microstructure of specimens and, the content and distribution of chemical components. The development of electron guns, such as FEG, and the improved lens system combined with the advanced in-lens detectors and STEM-inSEM system have expanded the applications of SEM. Automated SEM-EDS analysis also greatly increases the amount of data, enabling more statistically reliable results. In addition, X-ray CT, XRF, and WDS, which are installed in scanning electron microscope, have transformed SEM a more versatile analytical equipment. The performance and specifications of the scanning electron microscope to evaluate ceramics were reviewed and the selection criteria for SEM analysis were described.
\end{abstract}

Key words : Ceramic, SEM, Microstructure, Performance, Specifications 


\section{1. 서론}

세라믹은 스마트폰의 부품에서부터 이차전지용 소재, 광통신소재 등 다양한 분야에서 핵심적인 재료로 사용되 고 있다. ${ }^{1)}$ 과거 전통세라믹으로만 인식되던 세라믹의 활 용 분야가 전자세라믹, 바이오 세라믹, 에너지 · 환경 세 라믹 등으로 확대되며 세라믹은 첨단 · 융합소재로 거듭 나고 있다. 이에 따라 첨단 세라믹 소재의 신뢰성과 결함 을 정밀하게 평가하기 위한 첨단 측정 장비의 활용도 증 가하고 있다. 이중에서도 주사전자현미경은 가장 광범위 하게 활용되는 분석 장비 중 하나로서 다양한 미세구조 분석과 공극률 분석 등에 널리 사용되고 있다..$^{2-5}$

전자현미경(electron microscope)은 광학현미경(optical microscope)의 분해능 한계를 극복하기 위해 발명되었 다. ${ }^{6}$ 광학현미경의 분해능은 광원인 빛의 파장에 의해 결정 된다는 Abbe의 법칙이 증명됨으로서, 광학 렌즈의 결함이 완벽하게 개선되더라도 빛보다 파장이 더 짧은 광원을 사 용하지 않는 한 광학현미경의 분해능은 더 이상 개선될 수 없다는 것이 드러났기 때문이다. ${ }^{6)} 1924$ 년 L. de Broglie 가 움직이는 전자는 파동의 성질을 갖는다고 주장한 가정 이 과학자들에 의해 증명되었고 자성 코일(magnetic coil)이 마치 볼록렌즈와 같은 효과를 낸다는 것이 $\mathrm{H}$. Busch에 의해 발견되었다. ${ }^{6}$ 움직이는 전자의 파장은 빛 의 파장과 비교해서 매우 짧았기 때문에 전자빔을 광원으 로 사용하고 볼록렌즈로 작용할 수 있는 코일을 조절하여 전자빔을 모으거나 펼칠 수 있는 전자현미경의 개발이 시 작되었다.

전자현미경은 이름 그대로 전자(electron)를 광원으로 사용하여 관찰하려는 대상의 확대된 상(image)을 얻는 현 미경이다. 전자빔이 시료를 투과하는가 또는 투과하지 않 고 표면을 주사(scan)하는가에 따라 전자현미경은 크게 투 과전자현미경(transmission electron microscope, TEM) 과 주사전자현미경(scanning electron microscope, SEM) 으로 나뉜다. 투과전자현미경에서는 전자빔을 구성하는 전자들이 서로 평행하지만 주사전자현미경에서는 수렴 시킨 전자빔을 사용한다는 차이가 있다. 전자현미경은 확 대된 상을 얻는다는 점에서 소재를 연구하는 현장에서 가
장 중요한 분석 장비 중 하나라고 할 수 있다. 특히 주사 전자현미경은 전자가 시료를 투과할 정도로 시료를 얇게 가공해야하는 투과전자현미경과 달리 최소한의 시료 준 비만을 거쳐 수 만 배 수십 만 배의 확대된 상을 관찰할 수 있다는 점에서 연구자들에게 접근하기 쉬운 분석 장비 라고 할 수 있다. 또한 광학현미경보다도 월등하게 큰 초 점 심도(depth of focus)를 갖기 때문에 입체적인 영상을 얻을 수 있다.

여러 개의 렌즈로 구성된 투과전자현미경보다 상대적 으로 구조가 간단한 주사전자현미경이 먼저 개발되었을 것 같지만 최초의 전자현미경은 투과전자현미경이었다. 최초의 투과전자현미경은 1931년 독일의 물리학자인 Max Knoll과 Ernst Ruska에 의해 발명되었다. ${ }^{6}$ Ernst Ruska가 1932년에 제작한 "Supermicroscope"의 배율 은 8,000 12,000배로 ${ }^{6}$ 오늘날 광학현미경과 비슷한 정 도였다. 렌즈 시스템이 투과전자현미경보다 간단하고, 가속전압과 분해능이 낮은 주사전자현미경의 개발은 이 보다 4년 후인 1935년 Max Knoll에 의해 시작되었다. ${ }^{7)}$ 독일의 Manfred van Ardenne교수는 주사전자현미경 의 중요한 원리가 담긴 논문을 1938 년에 출판하였다. Ardenne교수는 투과전자현미경에 주사 코일(scan coil) 을 추가하여 전자빔의 크기를 줄이는데 성공하고 이 빔이 시료를 주사하도록 하였다. ${ }^{7}$ 현대적인 형태의 주사전자 현미경은 영국의 Sir Charles W. Oatley에 의해 1948년 부터 1961년 사이에 개발되었다. ${ }^{7)}$ 2차전자(secondary electron, $\mathrm{SE}$ )를 노이즈없이 검출할 수 있는 검출기를 발 명한 Thomas E. Everhart는 주사전자현미경의 상업적 생산의 길을 열었다고 할 수 있다. 상업적으로 주사전자 현미경을 처음 판매한 때는 1965 년이었는데 당시 제작된 주사전자현미경은 전자총 부분이 시료 챔버(specimen chamber)보다 크고 패널에는 수 많은 조절 나사가 달려 있었다.

투과전자현미경보다 사용이 쉬운 듯 보이지만 촬영 배 율이 수만 배 이상이 되면 전자총이나 전자기 렌즈의 배 열, 렌즈의 비점수차 보정 등을 수행해야 좋은 사진을 찍 을 수 있다. 주사전자현미경을 실험자가 직접 사용할 경 우 실험자의 지식과 숙련도에 따라 얻어지는 데이터의 질 


\section{특 집 ㅃㅃ 이수정}

과 신뢰성이 크게 달라진다. 주사전자현미경의 원리와 얻 을 수 있는 데이터의 종류, 신뢰할 수 있는 데이터를 얻기 위해 주의해야 할 점 등 기초적인 지식을 갖추고 사용 경 험을 쌓는 것이 필요하다. 본 논문에서는 어려운 이론보 다는 사용자가 알아야 할 주사전자현미경의 원리와 특징, 장점과 한계점, 시료 준비법 등을 설명하고자 한다. 마지 막으로 사용자의 분석 목적과 시료의 특징에 따라 어떤 성능을 갖춘 주사전자현미경을 선택하는 것이 적합한지 에 대해 기술할 것이다.

\section{2. 주사전자현미경의 윈리}

주사전자현미경은 크게 현미경 컬럼(column)과 제어반 (control console)의 두 부분으로 구성되었다고 볼 수 있 다. 현미경 컬럼은 전자빔을 발생시키는 전자총(electron gun), 전자기 렌즈(electromagnetic lens), 주사 코일, 시 료 챔버, 각종 검출기로 구성되어 있다. 전자총에서 발생 된 전자빔이 전자기 렌즈를 통과해 시료에 주사되도록 이 동되기 위해 컬럼은 항상 일정한 진공상태로 유지된다. 시 료를 챔버 안 시료대에 장착한 후 진공이 일정 수준에 도 달하면 전자빔을 발생시키기 위해 가속전압을 올려 시료 를 관찰하게 된다.

\section{1 전자총(electron gun) 또는 에미터(emitter)}

전자를 방출하는 소스(source)를 전자총 또는 에미터 라고 한다. 전자를 에미터로부터 방출시키는 방식은 크게 2가지로 나뉜다. 첫째, 열전자(thermal electron)를 방 출시키는 방식으로 텅스텐 헤어핀이나 $\mathrm{LaB6}$ 결정을 $2800 \mathrm{~K}$ 이상의 높은 온도로 가열하는 것이다(Table 1).
텅스텐 필라멘트는 저렴하고 빔 전류가 안정적이어서 주 사전자현미경의 에미터로 널리 사용된다. 텅스텐 필라멘 트의 단점은 수명이 10 100 시간으로 짧아서 자주 교체 해야하고 전자빔의 크기가 커서 고분해능 영상 촬영에는 적합하지 않다는 것이다(Table 1). 텅스텐 필라멘트보다 수명이 긴 LaB6 결정은 수명이 200 1,000 시간정도로 길고 전자빔 크기도 텅스텐 헤어핀보다는 훨씬 작은 5 50um이다(Table 1). 열전자를 방출하는 방식의 주사 전자현미경에서는 사용자의 편의에 따라 텅스텐 필라멘 트나 $\mathrm{LaB}_{6}$ 결정을 선택하며 에미터의 수명은 사용자의 관리 상태에 따라 크게 달라진다. 두 번째의 전자 방출 방 식은 전계방출형(field emission)인데, 이는 끝 부분의 직경이 $100 \mathrm{~nm}$ 이하가 되도록 아주 뾰족하게 가공한 텅 스텐 와이어에 전기장을 걸어 전자를 방출시키는 방식이 다.8) 전계방출형 에미터의 장점은 수명이 1,000 시간 이 상으로 길고 전자빔의 크기를 나노미터 수준으로 매우 작 게 만들 수 있으며 에너지 스프레드가 열전자에 비해 매 우 적다는 점이다(Table 1). 전계방출형 에미터는 상온에 서 사용되는 CFEG(cold field-emission electron gun)와, 열전자 방출 온도보다 낮은 1600 1800K 정도의 저온으로 가열하며 동시에 전기장을 걸어주는 쇼트키(Schottky) 또 는 TFEG(thermal field-emission electron gun)으로 다 시 구분된다(Table 1). CFEG 에미터는 소스의 크기와 에 너지 퍼짐이 작아서 고분해능에 유리하지만 빔 전류가 낮 고 안정성이 떨어지는 단점이 있다. 쇼트키는 열전자형 에미터와 $\mathrm{CFEG}$ 의 장점을 모두 갖도록 설계된 것으로, 강한 전기장을 걸어 상대적으로 저온에서 열전자가 방출 되도록 만든 것이다. $\mathrm{CFEG}$ 보다 소스는 다소 크지만 에 너지 퍼짐이 열전자보다 훨씬 작고, 빔 전류와 빔의 안정

Table 1. 가속전압 20kV에서 전자총(에미터)의 특성 비교 ${ }^{8)}$

\begin{tabular}{|c|c|c|c|c|c|}
\hline 에미터 유형 & $\begin{array}{c}\text { 명도 } \\
(\mathrm{A} / \mathrm{cm} 2 \mathrm{sr})\end{array}$ & 수명(h) & 소스 크기 & $\begin{array}{c}\text { 에너지 퍼짐 } \\
(\mathrm{eV})\end{array}$ & 빔 전류 안정성 $(\% / \mathrm{h})$ \\
\hline $\begin{array}{l}\text { 텅스텐 } \\
\text { 헤어핀 }\end{array}$ & $10^{5}$ & $10-100$ & $30-100 \mu \mathrm{m}$ & $1-3$ & 1 \\
\hline LaB6 & $10^{6}$ & $200-1,000$ & $5-50 \mu \mathrm{m}$ & $1-2$ & 1 \\
\hline CFEG & $10^{8}$ & $>1,000$ & $\langle 5 \mathrm{~nm}$ & 0.3 & 5 \\
\hline 쇼트키 & $10^{8}$ & $>1,000$ & $15-30 \mathrm{~nm}$ & $0.3 .-1.0$ & $\sim 1$ \\
\hline
\end{tabular}


성은 $\mathrm{CFEG}$ 보다 우수하여 화학 분석에도 적합하다 (Table 1). 따라서 화학분석보다 깨끗한 고분해능 영상을 얻어야 한다면 $\mathrm{CFEG}$ 가 장착된 현미경을, 고분해능 영상 과 함께 화학분석이 중요하다면 쇼트키 타입의 현미경을 선택할 수 있다. 수만 배 정도 배율의 영상과 화학분석은 텅스텐이나 $\mathrm{LaB}_{6}$ 가 장착된 주사전자현미경으로도 충분 하다.

\section{2 전자기 렌즈}

주사전자현미경에서 전자기 렌즈의 역할은 에미터에서 방출된 전자빔이 모아진 빔 크로스오버(beam crossover) 를 작게 만들어 시편에 조사시키는 것이다. 텅스텐 열전 자의 경우 빔 크로스오버의 직경이 $50 \mu \mathrm{m}$ 이고 이것을 약 $10 \mathrm{~nm}$ 크기로 시편에 조사시킨다고 가정하면 5 천배가 축 소되어야 한다. 전자기 렌즈에 흐르는 전류값을 조절하면 마치 볼록렌즈로 빛을 모으듯이 전자빔의 크기를 작게 만 들 수 있다.

전자기 렌즈는 감겨진 코일을 철로 된 외피가 감싸고 있는 형태를 갖고 있다. 렌즈 코일에 걸어주는 전류값을 변화시키면 렌즈의 초점 거리(focal length)가 변하기 때 문에 상이 확대되거나 축소된다. 초점 거리는 전자기 렌 즈가 얼마나 많이 상을 축소시킬 수 있는가를 의미하는 척도가 된다.

사용자가 시료가 뚜렷하게 보이도록 초점 나사를 조절 하면 대물렌즈(objective lens)의 전류 값이 변화된다. 즉 초점을 맞추기 위해 사용자는 대물렌즈의 초점 거리를 변 화시키는 것이다. 따라서 초점을 맞추다보면 $\mathrm{WD}$ (working distance)는 물론 배율도 약간 달라진다. 초점이 정확하 게 맞춰지면 $\mathrm{WD}$ 와 배율을 다시 조절하도록 한다. 대물
렌즈는 상부에 위치한 콘덴서 렌즈(condenser lens)보다 훨씬 큰 전류가 흐르는 강한 렌즈이기 때문에 냉각이 필 요하다. ${ }^{8)}$ 영상을 촬영하거나 $\mathrm{EDS}$ 분석을 수행할 때는 콘 덴서 렌즈의 전류 값을 변화시켜 스팟 크기(spot size)를 조절하게 된다. 표면을 관찰하거나 고배율에서는 작은 스 팟을, $\mathrm{EDS}$ 분석을 할 때는 큰 스팟을 사용해야 충분한 강도의 X-선을 수집할 수 있다.

\section{3 검출기}

주사전자현미경에서 시료 표면의 형상을 입체적으로 관찰하기 위해 2 차전자를 수집하는 검출기가 있다. 2차 전자 검출기로 널리 사용되는 $\mathrm{E}-\mathrm{T}$ 검출기(EverhartThornley detector)는 시료 챔버의 측면에 설치된다. $\mathrm{E}-\mathrm{T}$ 검출기의 원리는 검출기 전면부의 콜렉터(collector) 에 양전압을 걸어 시료에서 발생하는 2 차전자를 모으는 것이다. ${ }^{7)} \mathrm{E}-\mathrm{T}$ 검출기는 구조가 간단하고 효율적이어서 많은 주사전자현미경에서 사용되고 있다.

전계방출형 에미터의 개발과 함께 새롭게 등장한 2 차전 자 검출기로 인렌즈(in-lens) 또는 쓰루 렌즈(throughlens)라고 부르는 형태가 있다. 이름처럼 2차전자 검출기 가 렌즈 내부에 위치함으로서 $\mathrm{E}-\mathrm{T}$ 검출기보다 2차전자 와 후방산란전자를 효과적으로 구분하여 검출할 수 있고 공간 분해능이 우수하다. ${ }^{8)}$ 특히 동일한 분석 조건에서 $\mathrm{E}-\mathrm{T}$ 검출기로는 볼 수 없는 표면의 특징을 구분할 수 있 다. ${ }^{9)}$ 인렌즈형 검출기는 가속전압에 상관없이 $\mathrm{E}-\mathrm{T}$ 검출 기보다 분해능이 2 배 가량 우수하다(Table 2). 인렌즈형 검출기로 들어오는 신호의 대부분은 시료에서 발생되는 2차전자(SE1)인 반면, $\mathrm{E}-\mathrm{T}$ 검출기에 잡히는 신호는 후 방산란전자에서 발생되는 2차전자(SE2)와, 후방산란전

Table 2. 가속전압 $1,3,15.20 \mathrm{keV}$ 에서 인렌즈형 검출기와 E-T 검출기로 얻은 2차전자 영상의 분해능9)

\begin{tabular}{ccc}
\hline 가속전압 $(\mathrm{keV})$ & 인렌즈 검출기의 분해능 $(\mathrm{nm})$ & $\mathrm{E}-\mathrm{T}$ 검출기의 분해능 $(\mathrm{nm})$ \\
\hline 1 & 2.0 & 2.3 \\
3 & 1.3 & 2.2 \\
15 & 1.2 & 2.4 \\
20 & 1.2 & 2.3 \\
\hline
\end{tabular}


특 집 ㅁㅃ 이수정

Table 3. 골드 시료로부터 발생된 2차전자를 E-T 검출기로 수집했을 때 2차전자의 성분22)

\begin{tabular}{ccc}
\hline 2차전자 & 근원 & 백분율 \\
\hline SE1 & 입사빔의 산란에 의해 발생 & 9 \\
SE2 & BSE에 의해 발생 & 28 \\
SE3 & 챔버 벽에 충돌한 BSE에 의해 발생 & 61 \\
SE4 & 렌즈 조리개에 충돌한 BSE에 의해 발생 & 2 \\
\hline
\end{tabular}

자가 시료 챔버의 벽 등에 충돌하면서 발생되는 2 차전자 (SE3)가 우세하다(Table 3). 골드와 같이 후방산란계수 가 높은 금속의 경우 $\mathrm{E}-\mathrm{T}$ 검출기로 들어오는 2 차전자의 $60 \%$ 이상이 SE3이다(Table 3). 다시 말해서 $\mathrm{E}-\mathrm{T}$ 검출 기는 2 차전자와 후방산란전자가 섞인 신호를 검출한다고 보아야 한다. ${ }^{8)}$ 인렌즈형 검출기가 부착된 주사전자현미 경에서 적절한 가속전압으로 시료를 관찰하면 더 높은 분 해능으로 시료 표면의 형태를 사실에 가깝게 관찰할 수 있다. 주사전자현미경에 따라서는 $\mathrm{E}-\mathrm{T}$ 검출기와 인렌즈 형 검출기가 모두 장착된 경우도 있는데, 인렌즈형 검출 기는 Upper SE detector, E-T 검출기는 Lower SE detector로 구분한다.

후방산란전자는 전자빔과 평행한 반대방향, 즉 후방으 로만 산란되지 않고 거의 모든 각도로 산란된다. 후방으 로 산란되는 경우가 가장 많고 에너지도 크기 때문에 2차 전자와 분리하는 것이 어렵지 않다(Fig. 1). 후방으로 산 란되는 전자만을 검출하는 검출기로 가장 흔한 유형은 대 물렌즈와 시료 사이에 장착되는 고체 다이오드(solid state diode)형 검출기이다. 이 검출기는 얇고 편평한 고

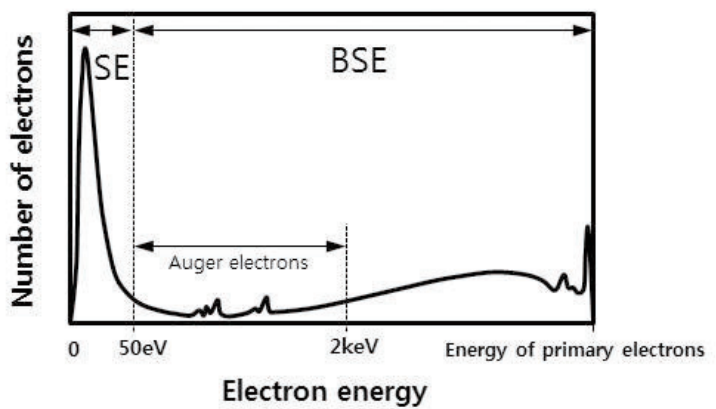

Fig. 1. 2차전자(SE)와 후방산란전자(BSE)의 에너지를 도식적으로 나타낸 그림.
리 형태의 와이퍼로 되어있다. 크기가 작고 얇기 때문에 시료와 가깝게 위치할 수 있고 효율적으로 후방산란전자 를 검출할 수 있다. 고체 다이오드는 에너지가 큰 후방산 란전자에만 민감하고 2 차전자의 영향은 받지 않기 때문 이다.8) 고체 다이오드는 정전용량(capacitance)이 커서 전자빔이 시료를 빠르게 주사하면 영상의 질이 좋지 않기 때문에 전자빔 주사 속도를 느리게 조절해야 좋은 영상을 얻을 수 있다. ${ }^{8}$

$\mathrm{Si}(\mathrm{Li}) \mathrm{EDS}$ 는 1960년대 개발되어 1968년 최초로 X-선 검출에 사용되었다. ${ }^{9)} \mathrm{EDS}$ 는 $\mathrm{WDS}$ (wavelength dispersive spectrometer)보다 신호처리 속도는 빠르지만 에너지 분 해능이 크게 떨어지는 단점을 갖고 있다. 에너지 분해능이 개선되었을 뿐만 아니라 신호처리 속도가 더 향상된 $\mathrm{SDD}$ (silicon drift detector)는 $\mathrm{EDS}$ 의 정량분석 결과의 신 뢰성을 크게 높였다. 펠티어 냉각(Peltier cooling)으로 $\mathrm{EDS}$ 를 사용할 때마다 액체 질소를 주입해야하는 불편도 개선되었다. 최근에는 $\mathrm{SDD} \mathrm{EDS}$ 가 일반화되는 추세이다.

$\mathrm{EDS}$ 분석 결과의 신뢰성은 시료의 표면 상태에 크게 영향받는다. 표면의 거칠기(roughness)가 $50 \mathrm{~nm}$ 가 되도 록 시료를 연마하여 준비하고 충분히 높은 X-선 강도를 얻어 정성분석을 올바르게 한다면 내부표준 물질의 분석 이 없더라도 $\mathrm{WDS}$ 에 준하는 매우 양호한 정량분석 결과 를 얻을 수 있다는 것이 알려졌다. ${ }^{10)}$ 그러나 $\mathrm{SDD}$ 가 $\mathrm{Si}(\mathrm{Li})$ 검출기와 비교하여 에너지 분해능이 개선되었다 하더라도 여전히 WDS보다 열등한 에너지 분해능을 갖고 있다. 특히 특성 $\mathrm{X}$-선이 겹치는 저에너지 범위에서는 소 프트웨어에서 자동으로 매칭된 결과를 분석자가 다시 점 검하고 확인할 필요가 있다(Table 4). 주사전자현미경에 서 $\mathrm{EDS}$ 분석을 할 때 가속전압은 대개 $20 \sim 25 \mathrm{kV}$ 를 사용 
Table 4. EDS 패턴에서 피크 겹침으로 오식별될 수 있는 원소별 특성 X-선 에너지 (200eV-5keV) $)^{23)}$

\begin{tabular}{|c|c|}
\hline 에너지 (keV) & 특성 X-선 에너지 \\
\hline $0.390-0.395$ & N K(0.392); ScLa $(0.3 .95)$ \\
\hline $0.510-0.525$ & $\mathrm{O} \mathrm{K}(0.523) ; \mathrm{V} \mathrm{L} \alpha(0.511)$ \\
\hline $0.670-0.710$ & F K (0.677); MnL $\alpha(0.636) ; \mathrm{FeL} \alpha(0.705)$ \\
\hline $0.845-0.855$ & $\mathrm{NeK} \alpha(0.848): \mathrm{NiL} \alpha(0.851)$ \\
\hline $0.900-0.950$ & $\mathrm{CuL} \alpha(0.928) ; \operatorname{PrM} \alpha(0.929)$ \\
\hline $1.00-1.05$ & $\operatorname{NaKa}(1.0441): \mathrm{ZnL} \alpha(1.012) ; \operatorname{PmM} \alpha(1.032)$ \\
\hline $1.20-1.30$ & $\operatorname{MgKa}(1.253) ; \operatorname{AsL} \alpha(1.282) ; \operatorname{TbM} \alpha(1.246)$ \\
\hline $1.45-1.55$ & $\operatorname{AlK} \alpha(1.487) ; \operatorname{BrL} \alpha(1.480) ; \operatorname{YbM} \alpha(1.521)$ \\
\hline $1.69-1.80$ & $\operatorname{SiK} \alpha(1.740) ; \operatorname{RbL} \alpha(1.694) ; \operatorname{SrL} \alpha(1.806) ; \operatorname{TaM} \alpha(1.709) ; \mathrm{WM} \alpha(1.774)$ \\
\hline $2.00-2.05$ & $\mathrm{P} \mathrm{K \alpha}(2.013) ; \operatorname{ZrL} \alpha(2.042) ; \operatorname{PtM} \alpha(2.048)$ \\
\hline $2.10-2.20$ & $\operatorname{NbL} \alpha(2.166) ; \operatorname{AuM} \alpha(2.120) ; \operatorname{HgM} \alpha(2.191)$ \\
\hline $2.28-2.35$ & $\mathrm{~S} \mathrm{K \alpha}(2.307) ; \operatorname{MoL} \alpha(2.293) ; \mathrm{PbM} \alpha(2.342)$ \\
\hline $2.40-2.45$ & $\operatorname{TcL} \alpha(2.424) ; \operatorname{BiM} \alpha(2.419)$ \\
\hline $2.60-2.70$ & $\operatorname{ClK} \alpha(2.621) ; \operatorname{RhL} \alpha(2.696)$ \\
\hline $2.95-3.00$ & $\operatorname{ArK\alpha }(2.956) ; \operatorname{AgL} \alpha(2.983) ; \operatorname{ThM} \alpha 1(2.996)$ \\
\hline $3.10-3.20$ & $\mathrm{CdL} \alpha(3.132) ; \mathrm{UM} \alpha 1(3.170)$ \\
\hline $3.25-3.35$ & $\mathrm{~K} \mathrm{K \alpha}(3.312) ; \operatorname{InL} \alpha(3.285) ; \operatorname{UM} \beta(3.336)$ \\
\hline $3.60-3.76$ & $\mathrm{CaK} \alpha(3.691) ; \mathrm{SbL} \alpha(3.605) ; \mathrm{TeL} \alpha(3.769)$ \\
\hline $4.05-4.15$ & $\operatorname{ScK} \alpha(4.090) ; \operatorname{XeL} \alpha(4.111)$ \\
\hline $4.45-4.55$ & $\operatorname{TiK} \alpha(4.510) ; \operatorname{BaL} \alpha(4.467)$ \\
\hline $4.84-4.95$ & $\operatorname{TiK} \beta(1.931) ; \operatorname{V~K} \beta(4.952) ; \operatorname{CeL} \alpha(4.840) ; \operatorname{PrL} \alpha(5.034)$ \\
\hline
\end{tabular}

한다. 특성 X-선은 입사되는 전자빔의 에너지보다 클 수 없기 때문에 $\mathrm{Ka}$ 가 $20 \mathrm{keV}$ 이상인 원소들은 L이나 M 선 으로 정성분석하게 된다. $\mathrm{X}$-선회절 분석에서와 마찬가 지로 정석분석을 올바르게 하려면 $\mathrm{EDS}$ 패턴에서 특성 $\mathrm{X}$-선의 위치와 상대적인 강도를 모두 고려하여 매칭하 여야 한다. EDS 소프트웨어에서 자동 매칭 결과는 올바 르게 되었는지 사용자가 반드시 점검하는 것이 좋다.

일반적으로 $\mathrm{EDS}$ 분석의 정량분석은 비표준 정량분석 (standardless quantitative analysis)이다. 어떤 분석 이든지 표준시료를 함께 분석하여야 완벽하게 정량분석 이라고 할 수 있다. EDS의 표준 정량분석에서 표준시료 는 화학조성이 정확하게 알려져 있고 전자빔의 크기에 비 교하여 성분이 균일하며, 진공이나 전자빔에 대해 안정되 고, 분석하려는 시료와 물리적, 화학적 성질이 비슷해야 한다. ${ }^{11)}$ 금속 시료의 경우 순수한 금속을 표준 시료로 사
용하는 것이 용이하지만 다성분 세라믹의 위의 조건을 만 족하는 표준시료를 준비하는 것은 쉽지 않다. 일반적으로 연마시료를 제작할 때 최종 연마제는 $1 \mu \mathrm{m}$ 다이아몬드 페 이스트를 사용한다. $\mathrm{EDS}$ 의 비표준 정량분석으로 보다 정확한 값을 얻으려면 앞에서 설명했듯이 시료 표면의 거 칠기를 더욱 줄이고 $\mathrm{SDD}$ 를 사용하는 것이 좋다.

\section{4 렌즈의 결함(Lens aberrations)}

광학 렌즈와 마찬가지로 전자기 렌즈도 결함을 갖고 있 다. 전자기 렌즈의 결함은 전자기 렌즈를 형성하는 코일 의 두께가 완벽하게 동일하지 않거나 코일이 완벽하게 원 의 형태로 감기지 않는 등의 원인으로 초래된다. 렌즈가 완벽하지 않기 때문에 광원에서 출발한 빔이 렌즈를 통과 하여 시료에 입사될 때 초점이 정확하게 한 점으로 맺어 지지 않는다. 광학 현미경에서는 렌즈를 추가하여 광학 
렌즈의 결함을 보완한다. 투과전자현미경의 경우 구면수차 (spherical aberration)와 색수차(chromatic aberration)를 줄이는 코렉터(corrector)나 단색화 장치(monochromator) 를 장착한다. 주사전자현미경에서는 사용자가 에미터와 렌 즈를 잘 정렬하고 비점수차(astigmatism)를 보정하는 것이 최선이다.

구면수차는 전자빔이 전자기 렌즈를 통과할 때 광축에 서 먼 지점에서는 더 강하게 휘기 때문에 광축에 가까운 지점을 지나는 전자빔과 초점을 맺히는 지점이 달라지는 현상이다.8) 렌즈를 통과하는 모든 전자빔이 한 지점에 모여 점을 이루지 못하고 타원이 된다. 구면수차는 렌즈 의 초점거리가 긴 핀홀렌즈(pinhole lens)의 경우 20 또 는 $30 \mathrm{~mm}$ 이지만 초점거리가 짧은 이머전(immersion)렌 즈나 스노켈(snorkel)렌즈에서는 수 $\mathrm{mm}$ 정도이다. ${ }^{8)}$ 구 면수차 계수는 대물렌즈의 조리개(aperture)를 작게 선 택함으로서 줄일 수 있지만 전자빔 전류도 함께 감소한다 는 것을 알아야 한다.

색수차는 에미터에서 발생된 수많은 전자의 에너지가 동일하지 않기 때문에 영상이 생성되는 영상 평면(image plane)에서 초점이 한 점으로 맺히지 않는 것을 말한 다. 8) 색수차는 가속전압이 낮을 때 더 커지는데 $3 \mathrm{keV}$ 에 서의 색수차는 $30 \mathrm{keV}$ 에서의 색수차의 10 배가 된다. ${ }^{8}$ 대 부분의 주사전자현미경에서 색수차는 구면수차 수치와 비슷하고 렌즈의 종류나 촬영 조건에 따라 달라진다.

비점수차는 전자기 렌즈를 구성하는 코일의 불균일한 두께, 완전한 원이 아닌 비대칭적인 형태, 폴피스의 불균 질성, 오염된 조리개 등으로 초점이 점으로 모이지 않고 2 개의 서로 수직인 선의 형태를 보이는 것이다. ${ }^{8)}$ 주사전 자현미경에는 스티그메이터(stigmator)라고 하는 4 쌍의 약한 자석이 설치되어 있어서 전자빔을 보다 대칭적이 되 도록 교정해준다. ${ }^{8)}$ 비점수차는 저배율에서는 무시할 정 도이고 잘 구분되지 않는다. 일반적으로 1 만 배 이상의 배 율에서는 비점수차를 보정하지 않으면 초점이 잘 맞춰진 깨끗한 영상을 얻기 힘들다. 비점수차가 완벽하게 교정되 면 초점을 흐렸다가 맞추는 과정을 Under focus-Just focus-Over focus로 반복했을 때 영상이 흐려졌다가 뚜 렷해지기만 할 뿐 서로 수직인 방향의 선 형태로 흐려지
는 현상은 나타나지 않는다. 비점수차를 조절하는 나사는 $\mathrm{x}$ 방향과 $\mathrm{y}$ 방향이 있는데, 하나의 나사를 조절하고 초점 을 맞춘 후 나머지 다른 나사를 조절하고 다시 초점을 맞 추는 과정을 반복하도록 한다.

\section{3. 전자빔-시료의 상호작용}

전자현미경에서는 음전하를 띤 무수히 많은 전자가 매 우 빠른 속도로 가속되어 시료에 입사된다. 전자는 입자 의 성격과 파동의 성격을 동시에 갖는다. 전자빔-시료의 상호작용은 전자의 입자로서의 특징으로 잘 설명된다. 전 자가 시료에 입사되면 시료를 구성하는 원소와 충돌하여 입사빔의 에너지를 거의 잃지 않는 탄성 산란(elastic scattering)이나 입사빔의 에너지가 시료를 구성하는 원 자로 전달되는 비탄성 산란(inelastic scattering)산란을 일으킨다. ${ }^{7,2)}$ 탄성산란과 비탄성산란에 의해 시료로부터 발생되는 전자의 수는 입사빔과 평행한 방향에서 최대이 고 입사빔으로부터 수직에 가까운 각도에서 최소가 된 다. 7) 따라서 주사전자현미경에서 시료로부터 발생되는 전자를 검출하기 위해 가장 효율적인 방법은 검출기를 입 사빔 방향, 즉 시료의 맞은편에 위치시키고 에너지의 크 기에 따라 전자를 검출하는 것이다.

전자빔과 시료의 상호작용이 일어나는 부피는 전자빔 에너지와 시료를 구성하는 원소의 종류에 좌우된다. ${ }^{7)}$ 전 자빔 에너지가 크면 투과력, 즉 시료에 조사되는 전자가 시료의 표면으로 침투하는 깊이가 증가된다.7) 가속전압 이 $30 \mathrm{kV}$ 일 때 탄소와 같은 가벼운 원소로 된 시료에서의 침투 깊이는 $10 \mu \mathrm{m}$ 정도인 반면 우라늄과 같이 무거운 원 소로 된 시료에서는 $0.5 \mu \mathrm{m}$ 에 불과하다. ${ }^{7)}$ 시료를 구성하 는 원소의 종류에 따라 전자빔-시료 상호작용 부피의 크 기뿐만 아니라 모양도 달라진다. 가벼운 원소로 이루어진 시료에서 전자빔-시료 상호작용 부피는 목(neck)이 있 는 서양배 또는 백열전구모양인 반면 무거운 원로로 된 시료에서는 구형에 가깝다. 전자현미경 영상은 전자빔시료 상호작용 부피에서 방출되는 신호로 만들어지기 때 문에, 이 부피가 크다는 것은 만들어진 영상이 표면의 정 보보다는 표면 아래 부분의 정보를 더 많이 담고 있음을 
의미한다. 2 차전자 영상으로 시료의 표면을 관찰하기 위 해 낮은 가속전압을 선택하는 것은 이런 이유 때문이다. 주사전자현미경에서의 전자빔과 시료의 상호작용은 유용한 정보를 담고 있는 신호를 발생시키는 것 외에 시 료에 일시적 또는 영구적인 변화를 초래할 수도 있다. 탄 성 산란은 결정질 시료 성분 원자의 전위(displacement) 나 시료 표면 원자의 스퍼터링(sputtering)을 야기한다 (Fig. 1). 비탄성산란은 2차전자와 X-선을 발생시켜 시 료에 대한 정보를 제공하지만 방사선 분해(radiolysis)를 일으켜 시료의 구조가 파괴되거나 질량이 감소되기도 한 다(Fig. 1). 입사 전자가 비탄성 산란될 때 입사 전자의 에 너지가 시료로 전달되면 국부적으로 시료를 가열하는 결 과를 가져온다. ${ }^{11)}$ 이러한 가열 효과는 상분해(phase decomposition)나 상변환(phase transformation), ${ }^{13)}$ 비 정질화(amorphization) 또는 결정화(crystallization)와 같은 결과로 나타난다. ${ }^{14)}$ 앞에서 설명한 전자빔에 의한 시 료의 훼손(damage)은 다양한 정도로 일어나는데 주로 시 료의 두께, 결정질 시료의 결정학적 방위, 전자현미경의 가속 전압, 빔 전류밀도와 빔 크기에 따라 달라진다. ${ }^{14)}$

\subsection{2차전자}

2차전자는 전자빔이 시료를 구성하는 원자의 바깥껍질 에 느슨하게 결합되어 있던 전자와 충돌할 때 시료로부터 탈출할 만큼의 운동 에너지를 얻어 공간으로 튀어나오는 전자이다. ${ }^{8)} 2$ 차전자는 1 차전자인 전자빔으로부터 운동 에너지를 전달받아 발생되기 때문에 에너지가 $50 \mathrm{eV}$ 이 하로 매우 작아서 표면으로부터 얕은 깊이에서만 탈출이 가능하다. ${ }^{7.8)}$ 이런 이유로 2 차전자 영상에 시료 표면의 정 보가 담겨있는 것이다.

앞에서 언급했듯이 2 차전자는 1 차전자인 전자빔이 시 료에 조사되어 비탄성 산란을 일으켜 시료로부터 전자가 2차적으로 발생된 것이다. 이것을 SE1이라고 한다. ${ }^{8)}$ 전 자빔이 시료에 입사되면 산란은 여러 차례 일어난다. 여 러 번의 산란을 거쳐 후방산란전자가 발생될 때 국부적으 로 후방산란전자에 의해 2차전자가 야기되는데 이를 $\mathrm{SE} 2$ 라고 한다. ${ }^{8)} \mathrm{SE} 2$ 는 후방산란전자에 의해 발생되기 때문에 SE1이 갖고 있는 시료 표면에 대한 정보가 아닌,
후방산란전자의 정보를 제공한다. SE1과 SE2 모두 E-T 검출기에 수집되기 때문에 2 차전자 영상인데도 시료의 성분 원소에 따른 명암의 차이가 관찰된다. 가속전압이 $5 \mathrm{keV}$ 이하로 매우 낮으면 전자빔의 침투력이 약해서 후 방산란전자가 탈출하는 깊이가 감소되지만 SE1은 가속 전압에 상관없이 표면에서만 발생된다. ${ }^{8)}$ 따라서 고배율 관찰이 필요하지 않다면 가속전압을 낮춰 $\mathrm{SE} 2$ 를 줄일 수 있어서 표면의 자세한 특징을 관찰할 수 있다. 가속전압 이 높으면 SE2가 늘어나기 때문에 2차전자 영상이라도 높낮이의 차이가 줄어 표면의 특징이 평면적으로 보인다. 2차전자 계수는 가속전압뿐만 아니라 원자번호에도 별로 영향 받지 않으며, 오직 표면의 상태에만 매우 민감하게 달라진다. 에지효과(edge effect)는 표면이 절단된 부분 이나 튀어나온 부분의 에지가 매우 밝게 보이는 현상이 다. 2 차전자가 표면뿐만 아니라 에지의 옆면에서도 발생 되기 때문에 2 차전자의 양이 많아 밝게 보이는 것이다.

\section{2 후방산란전자}

후방산란전자는 대체로 입사되는 전자빔 에너지의 $0.7 \sim 0.9$ 배의 에너지를 갖는 고에너지 신호이다. ${ }^{8)}$ 전자 가 자신보다 질량이 매우 크고 양전하를 띠고 있는, 시료 를 구성하는 원소의 원자핵에 의해 산란될 때 운동에너지 를 잃지 않고 진행방향만 바뀌게 된다. 이러한 산란이 일 어날 확률은 원자번호의 제곱에 비례하고, 무거운 원자일 수록 더 큰 양전하를 갖기 때문에 후방산란전자가 더 많 이 발생된다. ${ }^{8)}$ 따라서 후방산란전자 영상에서 가벼운 원 소로 된 부분은 어둡게, 무거운 원소로 이루어진 부분은 밝게 보인다.

후방산란전자 계수는 원자번호가 커질수록 증가하는 경향을 보이지만 전자빔 에너지에는 별로 영향을 받지 않 는다. ${ }^{8)}$ 그러나 입사빔이 시료에 조사되어 여러 차례의 산 란을 겪은 후 표면에서 탈출하는 깊이는 낮은 가속전압에 서는 급격하게 감소하기 때문에 후방산란전자 영상은 표 면의 특징을 반영하게 된다. ${ }^{8)}$ 입사 전자를 기준으로 후방 으로 진행하는 후방산란전자는 에너지가 크고 탈출 깊이 가 상대적으로 깊기 때문에 시료를 구성하는 원소 성분의 정보를 제공하기에 적당하다. 


\section{3 특성 $X-$ 선}

주사전자현미경이 강력한 분석 툴이 될 수 있는 이유는 광학현미경과 달리 에너지분산 분광분석기(energydispersive spectrometer, $\mathrm{EDS}$ )를 장착하여 확대된 영상 관찰과 함께 화학 분석을 동시에 수행할 수 있다는 점이 다. 전자빔이 시료에 조사되어 생성되는 신호 중에는 X선도 있다.

이 때 방출되는 X-선은 입사 전자나 후방산란전자, 고 에너지 2차전자가 시료 구성원자의 안쪽 껍질에 존재하는 원자를 튕겨낼 때 발생되는 것(특성 X-선)과, 시료 구성 원자의 원자핵과 상호작용할 때 발생되는 것(백색 X-선) 으로 크게 나눌 수 있다. ${ }^{7)}$ 안쪽 껍질의 전자가 튕겨져 제 거되면 원자는 이온화되어 불안정해진다. 이를 해소하기 위해 바깥 껍질로부터 전자가 안쪽 껍질로 이동하여 비어 있는 자리를 메꾸게 된다. 에너지 준위가 높은 바깥 껍질 에서 에너지 준위가 낮은 안쪽 껍질로 전자의 천이가 일어 나면 에너지 준위의 차이만큼을 잃게 되고 이 손실되는 에 너지의 양만큼이 X-선으로 발생된다.

보어(Bohr)의 모델에서 전자 껍질은 원자핵에 가까운 껍질부터 $\mathrm{K}, \mathrm{L}, \mathrm{M}, \mathrm{N}, \mathrm{O}$ 로 명명된다. $\mathrm{K}$ 껍질의 전자가 제거되고 $\mathrm{L}$ 껍질로부터 $\mathrm{K}$ 껍질로 전자가 이동될 때 발생 되는 $\mathrm{X}$-선을 $\mathrm{K} \alpha$ 로 명명한다. ${ }^{7)} \mathrm{M}$ 껍질에서 $\mathrm{K}$ 껍질로 전 자가 이동될 때 발생되는 $\mathrm{X}$-선은 $\mathrm{K} \beta$ 라고 한다. ${ }^{7)} \mathrm{K}$ 껍질 에는 $\alpha 1$ 과 $\alpha 2$ 두 개의 에너지가 존재하기 때문에 $\mathrm{KaX}$ 선에는 $\mathrm{Ka} 1$ 과 $\mathrm{Ka} 2$ 가 존재한다. ${ }^{7)}$

이러한 명명법은 $\mathrm{L}, \mathrm{M}$ 껍질에 그대로 적용된다. 전자 가 갖는 불연속적인 에너지 값은 원자마다 고유하고, 전 자의 천이로 발생되는 $\mathrm{X}$-선 에너지의 값은 하나의 원자 에서도 전자의 천이가 일어나는 전자 껍질마다 다르다. 따라서 마치 지문처럼 원소의 종류를 구분할 수 있는 지 시자로 활용할 수 있으며, 발생되는 X-선의 강도로 시료 에 존재하는 원소의 함량을 결정할 수 있다. 전자현미경 에 관한 문헌에는 원소마다 $\mathrm{K} \alpha, \mathrm{K} \beta, \mathrm{L} \alpha$ 등 전자의 천이 가 일어날 때 발생되는 X-선의 에너지 값이 기재되어 있 다. $\mathrm{EDS}$ 검출기 소프트웨어는 이 값들이 입력되어 있어 서 자동으로 $\mathrm{EDS}$ 피크가 원소와 매칭된다.

\section{4 전자빔에 의한 시료의 손상}

금속과 달리 세라믹 시료는 대부분 전기적 부도체이다. 주사전자현미경에서는 투과전자현미경에서보다 훨씬 낮 은 가속전압을 사용하지만 주사전자현미경에서도 시료 는 손상될 수 있다. 전자빔에 의한 시료의 손상으로 세라 믹 시료에서 가장 흔히 관찰되는 것은 에지처럼 튀어 나 온 부위에 정전하(electrostatic charging)가 쌓여 특히 매우 밝게 보이거나 밝고 어두운 선들이 나타나는 현상이 다(Fig. 2). 이외에 시료의 두께와 열전도도, 표면 상태에 따라 차이는 있지만 가열(heating)되는 효과가 있다 (Fig. 2). 높은 가속전압에서는 입사되는 전자빔의 침투 (penetration)가 크기 때문에 시료를 구성하는 원자가 제 거될 수도 있다(Fig. 2). 공유결합과 이온결합성 물질인 세라믹의 경우 방사선 분해(radiolysis)를 겪을 수 있다.

전자빔에 의해 시료가 손상되면 사진 촬영이 어려워지 거나 시료가 전자빔에 변형된 것을 시료의 고유한 특징으 로 잘못 기재할 수도 있다. 따라서 관찰하기 전에 시료의 특성에 대해 충분히 이해하고 시료의 손상을 최소화하며 시료를 관찰할 수 있는 방법을 찾는 것이 좋다.

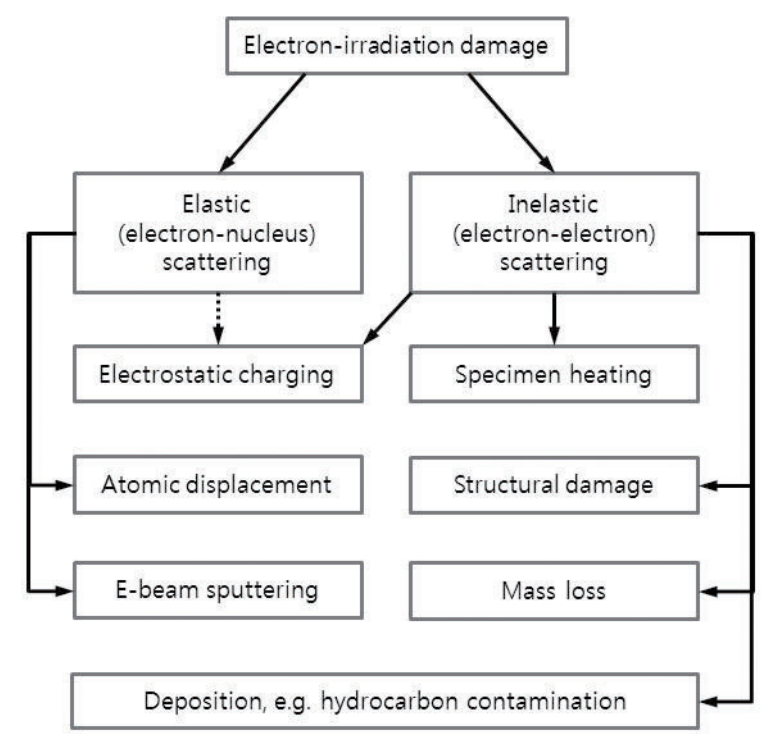

Fig. 2. 전자의 산란에 의한 전자빔 조사 손상 효과. ${ }^{12)}$ 


\section{4. 세라믹 시료의 준비법}

세라믹 시료를 주사전자현미경에서 관찰하기 위한 가 장 기본적인 준비는 반드시 전도체 막으로 코팅하는 것이 다. 만약 어떤 특별한 이유로 코팅을 하지 않고 관찰하려 면 저진공으로 관찰이 가능한 환경주사전자현미경 (environmental scanning electron microscope, $\mathrm{ESEM}$ )이나 일반 주사전자현미경에서 저진공이 가능한 기종을 선택하여야 한다.

전도체 코팅의 경우 탄소, 골드, 백금 등을 흔히 사용하 는데 코팅의 두께는 $5 \sim 20 \mathrm{~nm}$ 가 적합하다. ${ }^{7)}$ 탄소의 $\mathrm{Ka}$ $\mathrm{X}$-선 에너지는 $0.277 \mathrm{keV}$ 로 매우 작아서 시료에서 나오 는 X-선을 가리거나 중복되지 않아 $\mathrm{EDS}$ 분석에 적합하 다. 진공 증착(vacuum deposition)시킨 $2 \mathrm{~nm}$ 두께의 탄 소 코팅은 시료의 표면을 전도성을 갖도록 균질하게 덮는 데에 충분하다고 알려져 있다. ${ }^{7)}$ 코팅의 두께를 측정하는 장치가 없을 경우, 흰 종이가 옅은 초콜릿 컬러로 보이는 정도가 적당한 것으로 기준을 삼을 수 있다. ${ }^{8)}$ 광택이 나 면서 밝은 회색을 띤 다면 다소 두껍게 코팅된 것이다.8) 순수한 골드나 골드:팔라디움(60:40) 코팅은 5 10nm 두께로 해야 영상 촬영이나 $\mathrm{EDS}$ 분석에 적합한 정도가 된다. ${ }^{7)}$ 골드 코팅을 했을 때 시료의 표면이 옅은 청동의 색처럼 보이면 대체로 적합한 두께이고 광택이 나며 골드 색상을 띠면 너무 두껍다고 간주된다. ${ }^{8)}$

전도체 코팅을 하면 시료로부터 2차전자와 후방산란전 자의 방출이 보다 쉬워지고 가열 효과를 감소시킬 수 있 으며 분말 시료를 탄소 테이프 층에 고정하는 효과를 볼 수 있다. ${ }^{7)}$ 무엇보다도 시료의 표면을 전도성으로 만들어 전하가 쌓이는 것을 막아준다. 전도체 코팅은 $\mathrm{EDS}$ 분석 결과에 영향을 주기 때문에 되도록 5-10nm 정도가 적합 하지만 정전하 쌓임 현상이 심할 경우 반복해서 코팅하기 도 한다.

1 만 배 이하의 저배율로 관찰할 때는 코팅 입자의 크기 가 큰 골드가 적당하고 그 이상의 배율에서는 흔히 백금 코팅이 사용된다. 크롬의 경우 입자 크기가 작아서 고배 율 코팅 물질로 적당하지만 쉽게 산화되는 단점이 있다. 사산화오스뮴 $\left(\mathrm{OsO}_{4}\right)$ 을 사용하여 오스뮴 금속의 매우 얇
게 코팅시킬 수 있는데, 사산화오스뮴은 악취나 나는데다 유독하기 때문에 큰 주의가 필요하다. ${ }^{8)}$

분말 시료의 경우 탄소 테이프나 스티커를 시료 스텁 (stub)에 붙이고 그 위에 분말을 뿌린 후 전도체 막으로 코팅한다. 이때 분말이 탄소 위에 한 층으로만 뿌려지고 입자위에 다른 입자가 쌓이지 않도록 해야 한다. 덩어리 (bulk) 시료의 경우 탄소 테이프 위에 관찰할 면이 위로 오도록 놓은 후 탄소 테이트로 옆면을 시료대와 연결되도 록 모두 감싸주거나 탄소나 은과 같은 전도체 페인트 (conductive paint)를 옆면에 꼼꼼히 바른 후 관찰할 면 을 전도체 코팅한다.

시료의 형상이나 미세구조를 관찰하는 것보다 $\mathrm{EDS}$ 분 석이 중요하다면 세라믹 시료를 레진에 고정시켜 연마편 으로 제작하는 것이 좋다. 앞에서도 설명했던 Newbury and Ritchie (2013)의 연구결과는 시표 표면의 거칠기가 $\mathrm{EDS}$ 분석 결과의 정확도에 어떻게 영향을 주는지 WDS 결과와 비교함으로서 비표준 $\mathrm{EDS}$ 정량분석의 정확도를 향상시키기 위해 어떻게 해야 하는 지를 잘 보여주었다.

분말 시료라 할지라도 화학 분석 결과의 신뢰도를 높이 고 싶다면 연마편으로 제작하는 것이 추천된다. 자동 연 마 장치 제조사는 대개 표준화된 매뉴얼과 연마제를 제공 하고 있고, 사용자는 시료의 성질에 따라 연마시간을 적 절히 조절할 수 있다. 분말 시료나 특정한 형태의 시료를 분석할 경우 되도록 굴곡이 적고 평편한 부위를 선택하도 록 한다.

\section{5. 자동화된 SEM-EDS 분석법}

자동화된 SEM-EDS 분석법이 1980년대부터 개발되 기 시작하였다. 이 분석법은 주사전자현미경의 영상 촬영 과 $\mathrm{EDS}$ 분석을 통합하여 자동화시키고 획득된 자료를 영 상 분석 프로그램으로 처리하는 것으로 구성되어 있다. 시료는 에폭시 레진에 포매(embedding)하여 연마한 후 표면을 탄소로 코팅한다. 연구자는 분석 목적에 따라 어 떤 분석모드를 사용하여 어느 정도의 면적을 분석하지 결 정하고, 분석 배율과 배경값의 제거, 전자현미경의 관찰 조건과 $\mathrm{EDS}$ 의 분석 조건 등을 입력한다. 분석이 시작되 
면 자료의 획득만 자동으로 이루어지고 촬영된 영상과 $\mathrm{EDS}$ 분석 결과는 연구의 목적에 맞게 사용자에 의해 판 단되고 분류된다.

$\mathrm{SEM}$ 기반의 자동화된 분석법이 보편화되는데 가장 기 여한 장비로 $\mathrm{QEMSCAN}$ 을 들 수 있다. QEMSCAN의 기 본 분석 방식은 후방산란전자 영상에 적절한 간격으로 이 루어진 그리드(grid)를 설정하고 그리드의 교차점에서 $\mathrm{EDS}$ 점 분석이 이루어지는 것이다. 자동화된 SEM-EDS 장비에는 일반적으로 2 대 이상의 $\mathrm{EDS}$ 를 장착하는데, 분 석 배율이 높고 그리드의 간격이 좁으면 $\mathrm{EDS}$ 분석에 소 요되는 시간이 길어진다. QEMSCAN과 유사한 시기에 MLA가 등장했는데, MLA에서는 후방산란전자 영상에서 명암이 다른 영역의 중심점에서 1 개의 $\mathrm{EDS}$ 점 분석이 이 루어진다. QEMSCAN에서처럼 일정한 간격의 그리드 상 으로 분석하는 모드도 가능하다. 자동화된 SEM-EDS 시 스템은 시멘트, 광물, 고고학, 석유 등 다양한 분야의 분 석 요구에 맞춰 여러 분석 모드를 갖추고 있다. 국내에는 한국지질자원연구원에 2010년에 MLA가 설치되어 운용 되고 있다. 현재 QEMSCAN과 MLA외에 Mineralogic, INCAMineral, TIMA, AMICS 등이 자동화된 SEM$\mathrm{EDS}$ 시스템으로 상용화되어있다.

자동화된 $\mathrm{SEM}-\mathrm{EDS}$ 분석 장비는 자료 획득이 자동화 되어 있기 때문에 분석자가 $\mathrm{EDS}$ 분석을 직접 하는 것과 비교하여 분석하는 넓이가 크게 증가하고 데이터의 양도 방대해진다. 배율과 분석 모드에 따라 달라지지만 일반적 으로 연마편 시료 1 개의 영상촬영과 $\mathrm{EDS}$ 분석에 3 6시 간이 소요되기 때문이다. 후방산란전자 영상은 수백 수 천 개, $\mathrm{EDS}$ 점 분석은 수 만 개 수십 만 개로 얻어지기 때문에 통계적으로 유의미한 결과를 얻을 수 있다.

자동화된 SEM-EDS 분석을 고고학 연구에 활용하여 고대 세라믹 유물의 기원을 추적하고 광물상 분석을 통한 제작 온도를 유추 ${ }^{15-16)}$ 하는 것이 가능하다. 시멘트 콘크리 트를 깊이별로 상분석하여 에트린자이트, 황산염, $\mathrm{CSH}$ 의 상대적인 함량을 평각할 수도 있다. 알칼리 실리카 반응 특성을 규명18)하거나 콘크리트의 공극률을 정량적 으로 분석19)에도 활용된 바 있다.

\section{6. 주사전자현미경의 선택}

주사전자현미경의 분해능을 좌우하는 가장 큰 요인은 렌즈의 결함과 에미터의 특성이다. 렌즈의 결함은 주로 구면수차와 색수차에 기인하는데 렌즈의 디자인을 변화 시키거나 보정 장치를 달아 줄일 수 있다. 에미터의 특성 중 빔의 밝기 밀도와 단색성(monochromaticity)이 크면 전자현미경의 분해능은 좋아진다. 전자빔의 에너지 스프 레드(energy spread)는 색수차뿐만 아니라 에미터의 특 성에도 좌우되는데, 주사전자현미경에서는 구면수차나 색수차보다 에미터의 종류가 분해능이나 영상의 질에 큰 영향을 준다. 일반적으로 나노 수준의 고분해능 영상을 촬영하려면 에미터가 $\mathrm{CFEG}$ 인 장비가 유리하고, 화학 분 석이 중요하다면 열전자와 $\mathrm{FEG}$ 의 장점을 모두 갖춘 쇼 트키 에미터가 장착된 장비를 선택하는 것이 좋다.

시료의 표면을 왜곡없이 고분해능으로 촬영하려면 거 의 순수한 SE1만을 검출할 수 있는 인렌즈 검출기가 갖 춰진 장비를 선택하도록 한다. 필요하다면 $\mathrm{WD}$ 를 최대한 줄이고 낮은 가속전압에서 관찰하는 것이 좋다.

시료의 확대된 영상이나 $\mathrm{EDS}$ 분석 모두 코팅이 되지 않은 상태가 가장 좋다. 세라믹 시료는 거의 대부분이 부 도체이기 때문에 코팅을 하지 않으면 관찰이 불가능하므 로 최소한의 두께로 전도체 코팅을 하도록 한다. 전자빔 에 손상되기 쉬운 시료의 경우 전도체 코팅의 두께를 증 가시킬 수 있지만 고배율에서 코팅 입자가 보일 수 있고 $\mathrm{EDS}$ 결과에 영향을 줄 수 있다. 이보다는 시료 챔버에 가 스 분자를 넣어 기압을 조절하여 전도체 코팅없이 시료를 관찰할 수 있는 VP-SEM(variable- pressure scanning electron microscopy)를 고려할 수 있다. ${ }^{8)}$ 시료가 너무 커서 전도체 코팅이 어려운 경우에도 $\mathrm{ESEM}$ 이나 $\mathrm{VP}-$ $\mathrm{SEM}$ 을 활용하면 좋다.

일반적으로 주사전자현미경에서 시료의 화학 분석에 $\mathrm{EDS}$ 를 활용하지만, 보다 정확한 정량 분석을 위해 $\mathrm{WDS}$ (wavelength-dispersive spectrometer)를 장착한 주 사전자현미경을 선택할 수도 있다. WDS는 $\mathrm{EDS}$ 보다 에 너지 분해능이 월등하고 미량(trace)원소의 검출 성능도 뛰어나기기기 때문에 $\mathrm{EDS}$ 로 빠르게 원소 함량을 점검하 
고 피크가 중복되어 정성분석이 어려운 원소나 미량원소 는 WDS로 분석하는 것이 유용하다.

입사빔 감속장치(beam deceleration)는 주사전자현미 경의 분해능과 명암을 개선시키는 효과를 준다. ${ }^{20)}$ 이 장 치는 시료에 높은 음의 바이아스 전압(bias voltage)을 걸어 전자빔이 시료에 도달하기 전에 감속되도록 만든다. 음으로 바이아스된 시료에서 2 차전자 또는 후방산란전자 가 발생되면 그라운드 상태인 시료 챔버의 벽면 등의 방 향으로 전자가 가속되기 때문에 더 높은 에너지를 갖는 상태로 검출기에 감지된다. ${ }^{20)}$ 따라서 저전압에서도 보다 뚜렷하고 분해능이 개선된 영상을 얻을 수 있고 세라믹 시료와 같은 부도체의 표면에 전하가 쌓이는 현상도 감소 된다.

STEM(scanning transmission electron microscopy) 은 투과전자현미경에 스캔 코일을 추가하여 작은 크기의 탐침(probe)을 시료 표면에 주사시켜 투과된 신호로부터 결정구조 및 화학 성분 정보를 얻는 장비이다. 주사전자 현미경에 STEM 시스템이 설치된 경우 저전압 STEM 또 는 STEM-in-SEM이라고 한다. ${ }^{21)}$ 시료는 투과전자현미 경 시료처럼 얇은 막이나 분말의 형태이어야 하고 투과전 자현미경에서 사용하는 그리드(grid) 위에 준비한다. 경 원소로 이루어진 나노 분말을 주사전자현미경에서 관찰 할 경우 전자빔이 시료를 투과하여 시료 밑의 탄소 테이 프로부터 나오는 배경값이 노이즈로 작용하게 된다. 이런 나노 분말 분석에 STEM 검출기를 사용, 투과된 전자빔 을 모아 영상을 만들면 $\mathrm{E}-\mathrm{T}$ 검출기로 얻은 영상보다 노 이즈가 훨씬 적다.

3 차원적으로 시료를 분석하여 시료를 파괴하지 않고 내부의 형태나조직을 분석할수 있는 X-선 CT(computed tomography)나 XRF(X-ray fluorescence)를 주사전 자현미경에 장착한 경우도 있다. 이런 장비들은 독립적인 형태가 아니라 주사전자현미경 챔버에 부착되는 소형 장 비로서 Micro-CT for SEM, Micro-XRF라고 부르기도 한다. 단독 $\mathrm{X}$-ray CT나 XRF와 비교하여 파워나 분석 성능은 떨어지지만 주사전자현미경에서 시료의 확대된 영상을 관찰하면서 3 차원적 분석(내부 구조나 공극 분포 등)과 정량분석을 할 수 있다는 장점이 있다.

\section{참고문헌}

1. 한국세라믹기술원, 2016 세라믹 기술백서, pp. 300.

2. S-M Sim, "Sample preparation for microstructural characterization of Ni-Yttria-stabilized zirconia anodes," Journal of the Korean Ceramic Society, 55, 376-380 (2018).

3. J. Bai, J. Piao, J. Gao, J. He, Q. Du, and C. Li, "Enhancement of porosity and strength of porous $\mathrm{Al}_{2} \mathrm{O}_{3}$ ceramics by $\mathrm{Al}\left(\mathrm{H}_{2} \mathrm{PO}_{4}\right)_{3}$ addition," Journal of the Korean Ceramic Society, 56, 350-353 (2019).

4. M.C.Chang, "Three Dimensionally Ordered Microstructure of Polycrystalline Zirconia Ceramics with Micro-Porosity," Journal of the Korean Ceramic Society, 53, 50-55 (2016).

5. W-J Kim and M-H Roh, "Texture Development in Liquid-Phase-Sintered $\beta-\mathrm{SiC}$ by Seeding with $\beta-\mathrm{SiC}$ Whiskers," Journal of the Korean Ceramic Society, 43, 152-155 (2006).

6. M.M. Freundlich, "Origin of the Electron Microscope," Science, 142 [3589] 185-188 (1963).

7. R.E. Lee, "Scanning Electron Microscopy and X-ray Microanalysis," PTR Prentice Hall, New Jersey, pp. 458 (1993).

8. J. Goldstein, D. Newbury, D. Joy, C. Lyman, P. Echlin, E. Lifshin, L. Sawyer, and J. Michael, "Scanning Electron Microscopy and X-ray Microanalysis," ${ }^{\text {rd }}$ Ed. Springer Science+Business Media, LLC, pp. 690 (2003).

9. B.J. Griffin, "A comparison of conventional EverhartThornley style and in-lens secondary electron detectors-A further variable in scanning electron microscopy," Scanning, 33, 162-173 (2011).

10. D.E. Newbury and W.M. Ritchie, "Is scanning electron microscopy/energy dispersive X-ray spectrometry(SEM/EDS) qantitative?" Scanning, 35, 141-168 (2013).

11. 금동화, 김긍호, 이확주 편저, "투과전자현미경 분석학신소재 분석 · 평가-," 청문각, pp. 419 (1996).

12. R.F. Egerton, P.Li, and M. Malac, "Radiation damage in the TEM and SEM," Micron, 35, 399-409 (2004).

13. S. Lee, Y.J. Kim, H. J. Lee and H-S Moon, "Electron beam-induced phase transformations from metakaolinite to mullite investigated by EF-TEM and HRTEM," Journal of the American Ceramic Society, 84, 2096-2098 (2001).

14. N. Jiang, "Electron beam damage in oxides: a review," Reports on Progress in Physics, 79, https://doi. 


\section{org/10.1088/0034-4885/79/1/016501}

15. R. Cossio, P. Davit, F. Turco, L. Operti, V. Pratolongo, R. Leone, G. Lamagna, and A. Borghi, "Automated SEM-EDS pottery classification based on minerochemical quantitative parameters: An application on ancient Greek pottery from Adrano (NE Sicily, Italy)," X-ray Spectrometry, 1-11 (2019).

16. C. Knappett, D. Pirrie, M.R. Power, I. Nikolakopoulou, J. Hilditch, G.K. Rollinson, "Mineralogical analysis and provenancing of ancient ceramics using automated SEM-EDS analysis(QEMSCAN): a pilot study on LBI pottery from Akrotiri, Thera," Journal of Archaeological Science, 38, 219-232 (2011).

17. S. Sahu, A. Snyder, S. Badger, and R.J. Lee, "Depth profiling and phase discrimination in deteriorated concrete utilizing scanning electron microscopy with automated point count analysis," Proceeding of 23rd International Conference on Cement Microscopy, April 29-May 3, 2001, Sheraton Upton Hotel, NM, US.

18. P. Stutzman, "Applications of Scanning Electron Microscopy in Cement and Concrete Petrography," in Petrography of Cementitious Materials, ed. S.

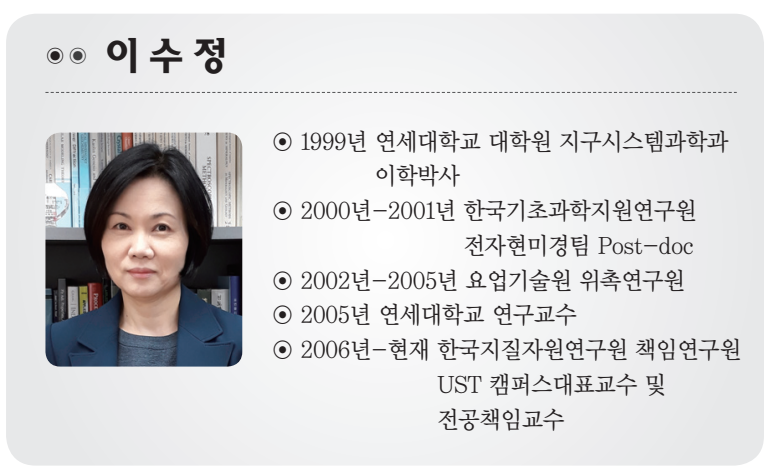

DeHayes and D. Stark (West Conshohocken, PA: ASTM International, 1994), 74-90.

19. R.S. Edwin, M. Mushthofa, E. Gruyaert, and N. De Belie, "Quantitative analysis on porosity of reactive powder concrete based on automated analysis of back-scattered-electron images," Cement and Concrete Composites, 96, 1-10.

20. D. Phifer, L. Tuman, T. Vystavel, P. Wandrol, and R.J. Young, "Improving SEM imaging performance using beam deceleration," Microscopy today, 17, 40-49 (2009).

21. A. Bogner, P-H Jouneau, G. Thollet, D. Basset, and C. Gauthier, "A history of scanning electron microscopy developments: Towards "wet-STEM" imaging," Micron, 38, 390-401 (2007).

22. Peters K-R Scanning electron microscopy: Contrast at high magnifica- tion. InMicrobeam Analysis-1984 (MS. Romig AD, Goldstein J). San Francisco Press (1984b) 77-80

23. D.E. Newbury, "Mistakes encountered during automatic peak identification in low beam energy X-ray microanalysis," Scanning, 29, 137-151 (2007). 